\title{
Changes in the Levels of Modern Biomarkers in Patients with Decompensated Heart Failure After Myocardial Infarction Under the Influence of Treatment with Succinic Acid and Arginine Preparations
}

\author{
Khrystyna Levandovska
}

\begin{abstract}
The prevalence of heart failure in Europe and worldwide is high. This syndrome is a common cause of hospitalization and has a significant impact on morbidity, mortality and healthcare costs in highly developed countries. The study of biomarkers in heart failure is of wide interest as they can improve diagnosis, predict the development of heart failure and its decompensation, and help in assessing treatment outcomes.

The objective of the research was to study the feasibility of using multiple biomarker strategy for diagnosing decompensated heart failure in the post-infarction period and to assess changes in these markers after treatment with succinic acid and arginine preparations.

Materials and Methods. There were examined 120 patients with Q-QS wave and non-Q wave myocardial infarction complicated by decompensated heart failure. All the patients were divided into 2 groups (depending on Q-QS wave and non-Q wave myocardial infarction) and 4 subgroups (depending on rehabilitation therapy) being homogenous by age and gender.

Results. When studying the dynamics of changes in blood level of N-terminal pro-B-type brain natriuretic peptide and ST2, there was observed its significant reduction in all the patients with prior Q-QS wave myocardial infarction complicated by decompensated heart failure after treatment. The most significant changes were observed in the patients of Group IV who, on the background of basic therapy, received succinic acid and arginine preparations according to the proposed scheme. The combined use of arginine preparations and succinic acid in combination therapy for decompensated heart failure secondary to prior Q-QS wave myocardial infarction allowed reducing blood levels of $\mathrm{N}$-terminal pro-B-type brain natriuretic peptide under conditions of graded exercises. Similar tendencies were observed when determining this indicator in the patients with non- $Q$ wave myocardial infarction complicated by decompensated heart failure after rehabilitation treatment.

Conclusions. The use of succinic acid and arginine preparations when treating the patients with prior QQS wave and non-Q wave myocardial infarction complicated by decompensated heart failure allowed us to significantly reduce the level of immunological enzymes such as $\mathrm{N}$-terminal pro-B-type brain natriuretic peptide and ST2, which indicate the presence and development of decompensated heart failure after myocardial infarction.
\end{abstract}

Keywords

decompensated heart failure; B-type brain natriuretic peptide; ST2; succinic acid; arginine preparations

Ivano-Frankivsk National Medical University, Ivano-Frankivsk, Ukraine

Corresponding author: levandovska87@ukr.net

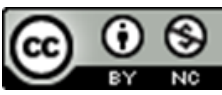

Copyright (C)Khrystyna Levandovska, 2019 


\section{Problem statement and analysis of the latest research}

According to the European Society of Cardiology (ESC), heart failure (HF) is defined as a clinical syndrome characterized by typical symptoms (e.g. shortness of breath, swollen and tired calf muscles) that are accompanied by the signs (e.g. elevated jugular venous pressure, peripheral oedema of the lower extremities) resulted from structural and/or functional cardiac changes due to a reduced cardiac output and elevated intra-cardiac pressure at rest or during exercise [7]. Since human life expectancy has increased, the incidence of HF and its decompensation has increased as well, resulting in significant costs to the healthcare system [6]. Decompensated $\mathrm{HF}$ accounts for 1, 110, 000 hospitalizations annually causing 60, 000 deaths worldwide which costs to local budgets $>39$ billion per year [1]. A significant proportion $(<40 \%)$ of these patients have $\mathrm{HF}$ with reduced ejection fraction $(\mathrm{EF})$, while the rest are diagnosed with HF with preserved and mid-range left ventricular (LV) EF [14]. Despite years of clinical research, cardiac biomarkers have been accepted as those used for routine assessment of cardiovascular diseases. According to current ESC guidelines, troponin and natriuretic peptides are preferred biomarkers, while amongst the most promising newer biomarkers, growth stimulation expressed gene 2 (ST2) has emerged as a promising one. These biomarkers are extremely valuable; however, none of them can be used independently, without the clinical context [2].

Natriuretic peptides, especially B-type brain natriuretic peptide (BNP) and its precursor N-terminal pro-B-type brain natriuretic peptide (NT-proBNP), are currently widely used in clinical practice and their measurement is recommended by the ESC as a part of diagnosis and management of HF [7]. Both BNP and NT-proBNP are very accurate and useful when diagnosing decompensated HF, as well as using them in routine clinical practice [8]. Despite an important role of these peptides when managing the patients with HF, the use of natriuretic peptides has certain limitations. Their increase is typical for valvular HF, pulmonary hypotension, pulmonary embolism, atrial fibrillation and sepsis as well [9].

ST2 is a member of the interleukin-1 (IL-1) superfamily, that binds to IL-33 and is a cytokine which is mainly secreted by cardiac fibroblasts in response to cell damage [3]. ST2 is a powerful predictive biomarker for HF both during stabilization and decompensation $[4,5]$ with two main isoforms: transmembrane receptor (ST2L) and soluble receptor (sST2) [10]. Effects of IL-33 such as its increase in response to myocardial stress, cardioprotective effect, reduction in myocardial fibrosis, prevention of cardiomyocyte hypertrophy and apoptosis, are manifested precisely by the ST2L receptor and are blocked when IL-33 binds to the sST2L receptor, that occurs when sST2L levels increase. This explains why sST2L levels increase in remodeling, hypertrophy in the patients with HF, especially in case of its development after prior myocardial infarction (MI) [3]. It is worth saying that the concentration of sST2 increases in bronchial asthma, rheumatoid arthritis, systemic lupus erythematosus and sepsis as well [11]. SST2 closely correlates with LV EF, disease severity, post-infarction LV remodeling; it is a predictor of pulmonary hypertension, right ventricular hypokinesis and jugular vein distension in acute decompensated HF [12]. Dieplinger et al. reported, that in healthy Austrian population, mean ST2 levels in men were $4-31 \mathrm{ng} / \mathrm{ml}$ and mean ST2 levels in women were $2-21 \mathrm{ng} / \mathrm{ml}[18,19]$, while, despite the same methods of the analysis, in healthy American population, these indicators were as follows: $8.6-49.3 \mathrm{ng} / \mathrm{ml}$ and $7.2-33.5 \mathrm{ng} / \mathrm{ml}$, respectively [20]. The MERLIN-TIMI-36 data showed that value of $35 \mathrm{ng} / \mathrm{ml}$ was acceptable; however, it is not conclusively known whether gender-based thresholds should be considered [13].

The results of the multiple-marker ProBNP Outpatient Tailored Chronic Heart Failure Therapy (PROTECT) sub-study of 151 patients with New York Heart Association (NYHA) functional class (FC) II to IV systolic $\mathrm{HF}$ ( $\mathrm{LVEF} \leq 40 \%$ ) indicated that the measurements of ST2, growth differentiation factor 15 (GDF-15) and high-sensitive troponin (hsTrop) provided an independent prognostic value [17]. In 2003, Weinberg et al. recorded that short-term changes in sST2 levels were prognostically valu- 


\section{Changes in the Levels of Modern Biomarkers in Patients with Decompensated Heart Failure After Myocardial Infarction Under the Influence of Treatment with Succinic Acid and Arginine \\ Preparations - 3/12 \\ able in diagnosing mortality or heart transplantation \\ 1. Materials and Methods}

regardless of NT-proBNP levels in the patients with HF [21].

Over the past four decades, treatment of the patients with LV systolic dysfunction has changed from digoxin and diuretics to a number of therapeutic strategies targeted to the main pathophysiological mechanisms of developing HF and its decompensation, including the effect on myocardial contractibility, vasodilation, inhibition of neurohumoral activation and anti-inflammatory pathways [15]. Modern treatment of the patients with HF and reduced LV EF after MI is based on the use of betablockers, angiotensin-converting-enzyme inhibitors, mineralocorticoid receptor antagonists [16]. As the heart is one of the most highly energy consuming organs, adjuvant therapy, that is aimed at increasing energetic metabolism, possesses cytoprotective and adaptive effects, reduces endothelial dysfunction and has a great potential [25]. Several preparations with antioxidant, anti-inflammatory, antiplatelet and hypolipidemic properties are known [24]. Among the groups of such preparations, succinic acid deserves special attention. Succinate, a salt or ester of succinic acid, is an important intermediate in the tricarboxylic acid cycle. In mitochondria, it plays a crucial role in generating adenosine triphosphate. Over recent years, it has been widely used in immunology and oncology $[22,23]$. Endothelial dysfunction is an important pathophysiological mechanism of developing HF and its decompensation, including disruption of the nitric oxide (NO) pathway [26]. The L-arginine-NO pathway is a complex system that affects vasomotor tone, cell adhesion, platelet aggregation, cell proliferation and angiogenesis [27]. Therefore, the use of arginine preparations in this group of the patients requires further study.

The objective of the research was to study the feasibility of using multiple biomarker strategy for diagnosing decompensated HF in the postinfarction period and to assess changes in these markers after treatment with succinic acid and arginine preparations.

There were examined 120 patients with Q-QS wave and non-Q wave MI, stage II A-B decompensated chronic HF according to the classification proposed by Vasylenko V.Kh. and Strazhesko M.D., NYHA FC III-IV. The patients with Q-QS wave MI (60 individuals) were divided into 4 groups depending on the treatment method: Group I comprised 15 patients who received basic therapy in accordance with the protocols of the Ministry of Health of Ukraine (lisinopril - $10 \mathrm{mg}$ once a day; bisoprolol fumarate - $10 \mathrm{mg}$ once a day; eplerenone $50 \mathrm{mg}$ once a day; valsartan - $40 \mathrm{mg}$ twice a day; ivabradine - $5 \mathrm{mg}$ twice a day); Group 2 included 15 patients who, on the background of basic therapy, received a preparation of succinic acid according to the proposed scheme; Group 3 included 15 patients who, on the background of basic therapy, received arginine preparations according to the proposed scheme; Group 4 comprised 15 patients who, on the background of basic therapy, received succinic acid and arginine preparations according to the proposed scheme. The patients with non-Q wave MI (60 individuals) were divided into 4 analogous groups. Tivortin - arginine hydrochloride manufactured by Yuria-Pharm, Kyiv, Ukraine; approved by the Order of the Ministry of Health of Ukraine of September 18, 2008 No 528, registration number UA/8954/01/01. An intravenous infusion of $4.5 \%$ Tivortin solution was administered at a dose of $100 \mathrm{ml}$ once a day at a drip rate of 10 drops per minute within the first 10-15 minutes by increasing drip rate to 30 drops per minute (within the first 10 days). Tivortin aspartate - L-arginine aspartate, aspartic acid manufactured by Yuria-Pharm, Kyiv, Ukraine; approved by the Order of the Ministry of Health of Ukraine of July 18, 2009, registration number UA/9941/01/01. The preparation was administered orally at a dose of $5 \mathrm{ml} 5$ times per day with a meal (the maximum daily dose is $8 \mathrm{~g}$ ) since the $11^{\text {th }}$ day of randomization for 15 days. Mexicor - 3-hydroxy-6-methyl-2-ethylpyridine succinate, solution for injections manufactured by LLC "Ekofarminvest", Russian Federation; approved by the Order of the Ministry of Health of Ukraine of 


\section{Changes in the Levels of Modern Biomarkers in Patients with Decompensated Heart Failure After Myocardial Infarction Under the Influence of Treatment with Succinic Acid and Arginine \\ Preparations - 4/12}

July 18, 2006, registration number UA/4971/01/01. The solution diluted in either sodium chloride or $5 \%$ dextrose in water was infused slowly at a dose of $100-150 \mathrm{ml}$ for 30-90 minutes 3 times per day every 8 hours within the first 10 days. The recommended daily therapeutic dose is $6-9 \mathrm{mg}$; the maximum single dose is $2 \mathrm{mg} / \mathrm{kg}$ of body weight. The maximum daily dose should not exceed 800 $\mathrm{mg}$; the maximum single dose is $250 \mathrm{mg}$. Mexicor ethyl-methyl-hydroxypyridine succinate, capsules manufactured by LLC "Ekofarminvest", Russian Federation; approved by the Order of the Ministry of Health of Ukraine of March 06, 2015, registration number UA/4971/02/01. The preparation was administered orally at a dose of $100 \mathrm{mg} 3$ times per day since the $10^{\text {th }}$ day of hospitalization for 5 months. The maximum therapeutic dose is $800 \mathrm{mg}$; the maximum single dose is $200 \mathrm{mg}$. The daily dose was divided into 3 doses given during the day. The patients were observed on the $1^{\text {st }}$ day of hospitalization and within the $1^{\text {st }}$ and $2^{\text {nd }}$ months after outpatient treatment.

Study groups were homogenous by age, gender, disease severity, duration of the post-infarction period, clinical signs of decompensation, that served as a basis for inclusion of the patients in the study.

Serum concentrations of NT-proBNP, ST2 were measured before treatment, 1 month and 2 months after treatment. All the patients underwent the sixminute walk test (6 MWT).

\section{Results and Discussion}

When studying the dynamics of changes in blood level of NT-proBNP, there was observed its significant reduction in all the patients with prior Q-QS wave MI complicated by decompensated HF after treatment (Table 1).

Thus, in the patients, who received basic therapy, the concentration of NT-proBNP reduced gradually from $(948.33 \pm 2.99) \mathrm{pg} / \mathrm{ml}$ at the beginning of treatment to $(780.33 \pm 3.18) \quad \mathrm{pg} / \mathrm{ml}$ and $(710.33 \pm 2.89) \mathrm{pg} / \mathrm{ml} 1$ and 2 months after the beginning of therapy, respectively $(\mathrm{p}<0.05)$, constituting $17.71 \%$ and $25.15 \%$ of the initial values. In the patients, who received succinic acid, there was observed a similar reduction in blood levels of NT-proBNP (by $26.38 \%$ and $29.09 \%$ ) - from $(951.27 \pm 3.10) \mathrm{pg} / \mathrm{ml}$ before treatment to (700.33 \pm 3.44$) \mathrm{pg} / \mathrm{ml}$ and $(674.53 \pm 2.61) \mathrm{pg} / \mathrm{ml} 1$ and 2 months after the beginning of treatment, respectively $(\mathrm{p}<0.05)$. In the patients of Group III, the level of NT-proBNP was $(952.00 \pm 2.33) \mathrm{pg} / \mathrm{ml}$ at the beginning of treatment and reduced by $21.27 \%$ and $24.26 \%$ - to $(749.53 \pm 3.60) \mathrm{pg} / \mathrm{ml}$, and 2 $(721.07 \pm 2.84) \mathrm{pg} / \mathrm{ml}(\mathrm{p}<0.05)$. The combined use of arginine preparations and succinic acid, when treating the patients with Q-QS wave MI and decompensated HF, allowed reducing blood levels of NT-proBNP by $41.03 \% 2$ months after the beginning of treatment. In this group, the level of NTproBNP was $(949.73 \pm 3.67) \mathrm{pg} / \mathrm{ml}$ before treatment, $(620.07 \pm 3.43) \mathrm{pg} / \mathrm{ml} 1$ month after the beginning of treatment and $(560.07 \pm 3.10) \mathrm{pg} / \mathrm{ml} 2$ months after the beginning of treatment $(\mathrm{p}<0.05)$.

The analysis of the dynamics of changes in NTproBNP level during graded exercises showed the differences in the effect of treatment on the dynamics of changes in the indicators. Thus, in the patients, who received basic therapy during all the observation periods, the level of NT-proBNP reduced gradually by $9.25 \%$ and $20.75 \% 1$ and 2 months after the beginning of treatment, respectively, that was significantly lower as compared to the patients before exercising. In the patients, who received succinic acid, the level of NT-proBNP reduced by $18.68 \%$ and $27.16 \%$ constituting $(1045.53 \pm 2.28) \mathrm{pg} / \mathrm{ml}$ before treatment, $(850.20 \pm 3.14) \mathrm{pg} / \mathrm{ml}$ and $(761.53 \pm 2.88) \mathrm{pg} / \mathrm{ml}$ after the beginning of treatment $(\mathrm{p}<0.05)$. There was no significant difference in the dynamics of changes in NT-proBNP levels after graded exercises in the patients, who, on the background of basic therapy, received arginine preparations. Thus, before treatment, NT-proBNP level was (1049.00 \pm 2.48$) \mathrm{pg} / \mathrm{ml}$, while 1 and 2 months after the beginning of treatment, it was $(919.33 \pm 3.15) \mathrm{pg} / \mathrm{ml}$ and $(800.53 \pm 3.16) \mathrm{pg} / \mathrm{ml}$, respectively $(\mathrm{p}<0.05)$. The combined use of arginine preparations and succinic acid in combination therapy for decompensated HF secondary to prior Q-QS wave MI allowed reducing blood levels of NT-proBNP under conditions of 
Table 1. Dynamics of changes in NT-proBNP indicators in the patients with decompensated HF after Q-QS wave MI during the course of treatment.

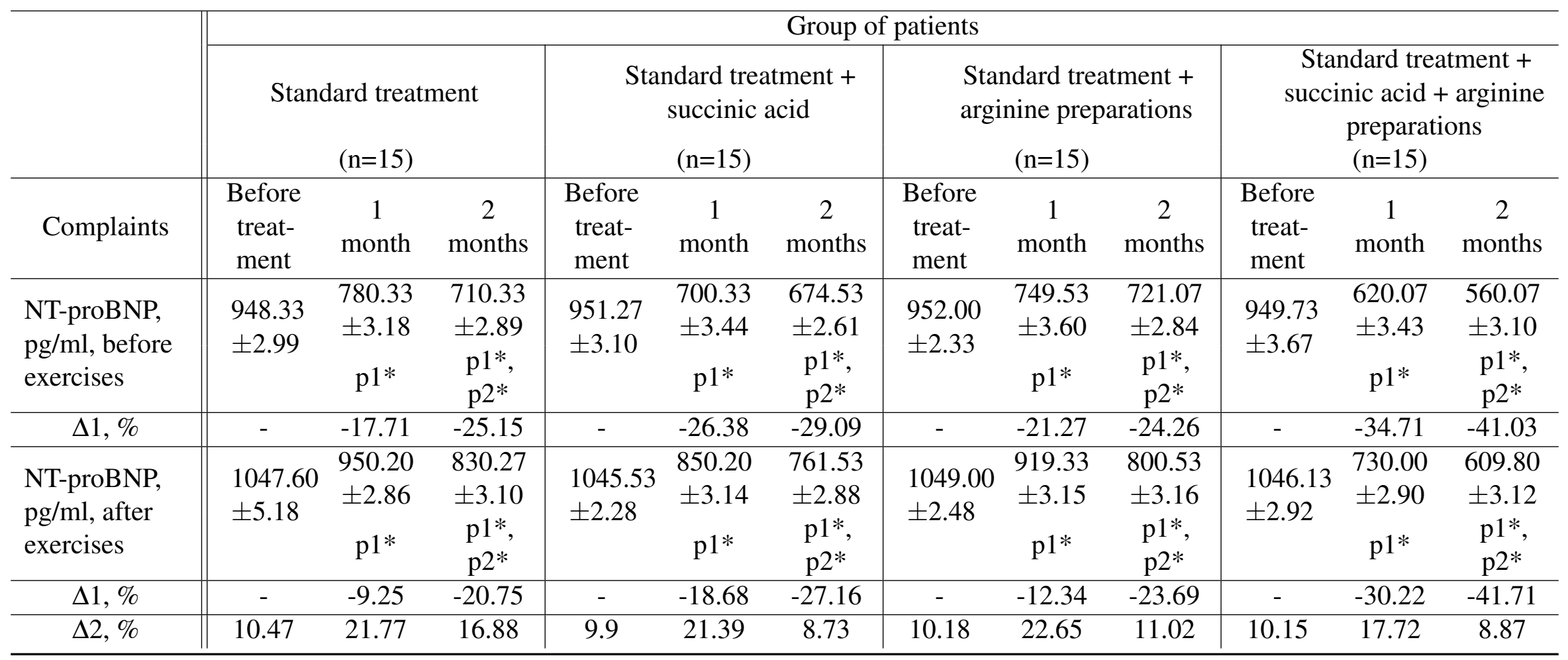

Notes:

1. the reliability of difference scores $\mathrm{p} 1$ - as compared to the indicators before treatment; $\mathrm{p} 2$ - as compared to the indicators 1 month after the beginning of treatment; $*-\mathrm{p}<0.05, * *-\mathrm{p}>0.05$.

2. $\Delta 1$ - the increase or reduction (-) in the indicator during the course of treatment as a percentage to the values before treatment.

3. $\Delta 2$ - the increase or reduction (-) in the indicator during the course of treatment as percentage depending on physical exercises. 
Table 2. Dynamics of changes in NT-proBNP indicators in the patients with decompensated HF after non-Q wave MI during the course of treatment.

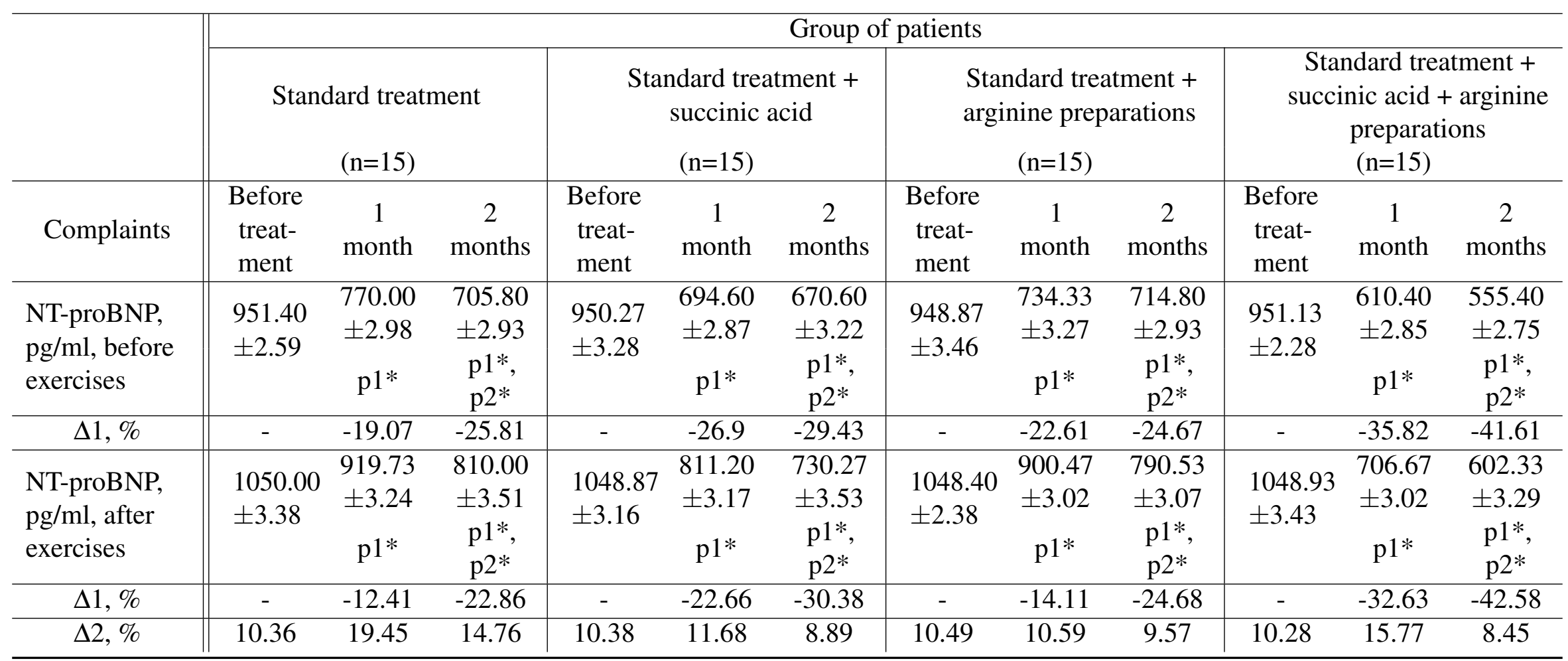

Notes:

1. the reliability of difference scores $\mathrm{p} 1$ - as compared to the indicators before treatment; $\mathrm{p} 2$ - as compared to the indicators 1 month after the beginning of treatment; $*-\mathrm{p}<0.05, * *-\mathrm{p}>0.05$.

2. $\Delta 1$ - the increase or reduction (-) in the indicator during the course of treatment as a percentage to the values before treatment.

3. $\Delta 2$ - the increase or reduction (-) in the indicator during the course of treatment as a percentage depending on physical exercises. 


\section{Changes in the Levels of Modern Biomarkers in Patients with Decompensated Heart Failure After Myocardial Infarction Under the Influence of Treatment with Succinic Acid and Arginine \\ Preparations - 7/12}

graded exercises. In this group of the patients, the level of NT-proBNP was $(1046.13 \pm 2.92) \mathrm{pg} / \mathrm{ml}$ before treatment and reduced to $(730.00 \pm 2.90) \mathrm{pg} / \mathrm{ml}$ and $(609.80 \pm 3.12) \mathrm{pg} / \mathrm{ml}(\mathrm{p}<0.05)$.

The analysis of the dynamics of changes in blood level of NT-proBNP showed its significant reduction during a 2-month observation period in all the patients (Table 2).

Thus, in the patients, who received standard therapy, the concentration of NT-proBNP reduced from $(951.40 \pm 2.59) \mathrm{pg} / \mathrm{ml}$ at the beginning of treatment to $(770.00 \pm 2.98) \quad \mathrm{pg} / \mathrm{ml}$ and (705.80 \pm 2.93$) \mathrm{pg} / \mathrm{ml} 1$ and 2 months after the beginning of treatment $(\mathrm{p}<0.05)$. In the patients treated with succinic acid, the level of NT-proBNP was $(950.27 \pm 3.28) \mathrm{pg} / \mathrm{ml}$ and reduced significantly by $29.60 \%$ and $29.43 \%$ after treatment $(694.60 \pm 2.87) \mathrm{pg} / \mathrm{ml}$ and $(670.60 \pm 3.22) \mathrm{pg} / \mathrm{ml}$, respectively $(\mathrm{p}<0.05)$. In the patients who, on the background of basic therapy, received arginine preparations, the level of NT-proBNP was (948.87 \pm 3.46$) \mathrm{pg} / \mathrm{ml}$ before treatment, and reduced to $(714.80 \pm 2.93) \mathrm{pg} / \mathrm{ml}$ after treatment $(\mathrm{p}<0.05)$. The combined use of arginine preparations and succinic acid on the background of standard therapy for non-Q wave MI and decompensated HF contributed to the reduction in blood levels of NT-proBNP by $35.82 \%$ and $41.61 \% 1$ and 2 months after the beginning of treatment. In this group, the level of NTproBNP was $(951.13 \pm 2.28) \mathrm{pg} / \mathrm{ml}$ at the beginning of treatment, $(610.40 \pm 2.85) \mathrm{pg} / \mathrm{ml} 1$ month after the beginning of treatment and $(555.40 \pm 2.75) \mathrm{pg} / \mathrm{ml}$ 2 months after the beginning of treatment $(\mathrm{p}<0.05)$.

The study of changes in NT-proBNP concentration during graded exercises showed certain differences in the effect of proposed schemata of therapy on changes in the indicators. Thus, in the patients with decompensated HF, who received standard therapy, the level of NT-proBNP reduced by $12.41 \%$ and $22.86 \% 1$ and 2 months after the beginning of treatment, respectively, that was significantly lower as compared to the patients before exercising.

In the patients, who received succinic acid, the level of NT-proBNP reduced by $22.66 \%$ and $30.38 \%$ 1 and 2 months after the beginning of treatment, constituting $(811.20 \pm 3.17)$ $\mathrm{pg} / \mathrm{ml}$ and
$(730.27 \pm 3.53) \mathrm{pg} / \mathrm{ml}$, respectively $(\mathrm{p}<0.05)$. There was no significant difference in the dynamics of changes in NT-proBNP levels in the patients, who received arginine preparations. The level of NTproBNP was $(1048.40 \pm 2.38) \mathrm{pg} / \mathrm{ml}$ and reduced by $24.68 \%$ to $(790.53 \pm 3.07) \mathrm{pg} / \mathrm{ml}$ after 2 months of treatment $(\mathrm{p}<0.05)$. In combined use of the proposed preparations on the background of standard therapy, the average value of this indicator was $(1048.93 \pm 3.43) \mathrm{pg} / \mathrm{ml}$ before treatment, whereas 1 and 2 months after the beginning of treatment, it was $(706.67 \pm 3.02) \mathrm{pg} / \mathrm{ml}$ and $(602.33 \pm 3.29) \mathrm{pg} / \mathrm{ml}$, respectively $(\mathrm{p}<0.05)$.

According to the data presented in Table 3, all the proposed schemata of therapy led to a significant reduction in serum level of this peptide after the end of treatment. In the patients of Group I, who received basic therapy, the median ST2 concentration before treatment was $(49.47 \pm 1.77) \mathrm{ng} / \mathrm{ml}$, while 1 and 2 months after the beginning of treatment, it was $(44.92 \pm 1.22) \mathrm{ng} / \mathrm{ml}$ and $(41.67 \pm 1.18) \mathrm{ng} / \mathrm{ml}$, respectively $(\mathrm{p}<0.05)$. When succinic acid was added to basic therapy, the level of this indicator before treatment was $(49.00 \pm 1.25) \mathrm{ng} / \mathrm{ml}$ reducing significantly by $22.31 \%$ and $26.67 \% 1$ and 2 months after the beginning of treatment to $(38.07 \pm 2.28) \mathrm{ng} / \mathrm{ml}$ and $(35.93 \pm 1.79) \mathrm{ng} / \mathrm{ml}$ $(\mathrm{p}<0.05)$. In the patients of Group III, who, on the background of basic therapy, received arginine preparations, the level of ST2 after 2 months of treatment was $(37.07 \pm 1.91) \mathrm{ng} / \mathrm{ml}$, that was significantly lower (by 22.98\%) as compared to that before therapy - $(48.13 \pm 0.99) \mathrm{ng} / \mathrm{ml}(\mathrm{p}<0.05)$. In the patients of Group IV, the concentration of ST2 before treatment was $(49.40 \pm 1.12) \mathrm{ng} / \mathrm{ml}$, significantly reducing by $28.80 \%$ and $41.30 \% 1$ month and especially 2 months after the beginning of treatment with succinic acid and arginine preparations to $(35.13 \pm 2.47) \mathrm{ng} / \mathrm{ml}$ and $(29.00 \pm 2.98) \mathrm{ng} / \mathrm{ml}$, respectively $(\mathrm{p}<0.05)$.

The effect of treatment in the patients with prior non-Q wave MI complicated by decompensated HF was analyzed.

According to the data presented in Table 4, in the patients, who received basic therapy, serum level of ST2 was $(48.93 \pm 1.83) \mathrm{ng} / \mathrm{ml}$ reducing signifi- 
Table 3. Dynamics of changes in ST2 indicators in the patients with decompensated HF after Q-QS wave MI during the course of treatment.

\begin{tabular}{|c|c|c|c|c|c|c|c|c|c|c|c|c|}
\hline \multirow[b]{3}{*}{ Complaints } & \multicolumn{12}{|c|}{ Group of patients } \\
\hline & \multicolumn{3}{|c|}{$\begin{array}{l}\text { Standard treatment } \\
\qquad(\mathrm{n}=15)\end{array}$} & \multicolumn{3}{|c|}{$\begin{array}{l}\text { Standard treatment }+ \\
\text { succinic acid } \\
(\mathrm{n}=15)\end{array}$} & \multicolumn{3}{|c|}{$\begin{array}{l}\text { Standard treatment }+ \\
\text { arginine preparations } \\
\qquad(\mathrm{n}=15)\end{array}$} & \multicolumn{3}{|c|}{$\begin{array}{c}\text { Standard treatment }+ \\
\text { succinic acid }+ \text { arginine } \\
\text { preparations } \\
(\mathrm{n}=15)\end{array}$} \\
\hline & $\begin{array}{c}\text { Before } \\
\text { treat- } \\
\text { ment }\end{array}$ & $\begin{array}{c}1 \\
\text { month }\end{array}$ & $\begin{array}{c}2 \\
\text { months }\end{array}$ & $\begin{array}{c}\text { Before } \\
\text { treat- } \\
\text { ment }\end{array}$ & $\begin{array}{c}1 \\
\text { month }\end{array}$ & $\begin{array}{c}2 \\
\text { months }\end{array}$ & $\begin{array}{c}\text { Before } \\
\text { treat- } \\
\text { ment }\end{array}$ & $\begin{array}{c}1 \\
\text { month }\end{array}$ & $\begin{array}{c}2 \\
\text { months }\end{array}$ & $\begin{array}{l}\text { Before } \\
\text { treat- } \\
\text { ment }\end{array}$ & $\begin{array}{c}1 \\
\text { month }\end{array}$ & $\begin{array}{c}2 \\
\text { months }\end{array}$ \\
\hline$\Delta, \%$ & & -9.19 & -15.77 & & -22.31 & -26.67 & & -12.47 & -22.98 & & -28.8 & -41.3 \\
\hline
\end{tabular}

Notes:

1. the reliability of difference scores $\mathrm{p}$ - as compared to the indicators before treatment; $\mathrm{p} 1$ - as compared to the indicators 1 month after the beginning of treatment; $*-\mathrm{p}<0.05, * *-\mathrm{p}>0.05$.

2. $\Delta-$ the increase or reduction (-) in the indicator during the course of treatment as a percentage to the values before treatment. 
Table 4. Dynamics of changes in ST2 indicators in the patients with HF after non-Q wave MI during the course of treatment.

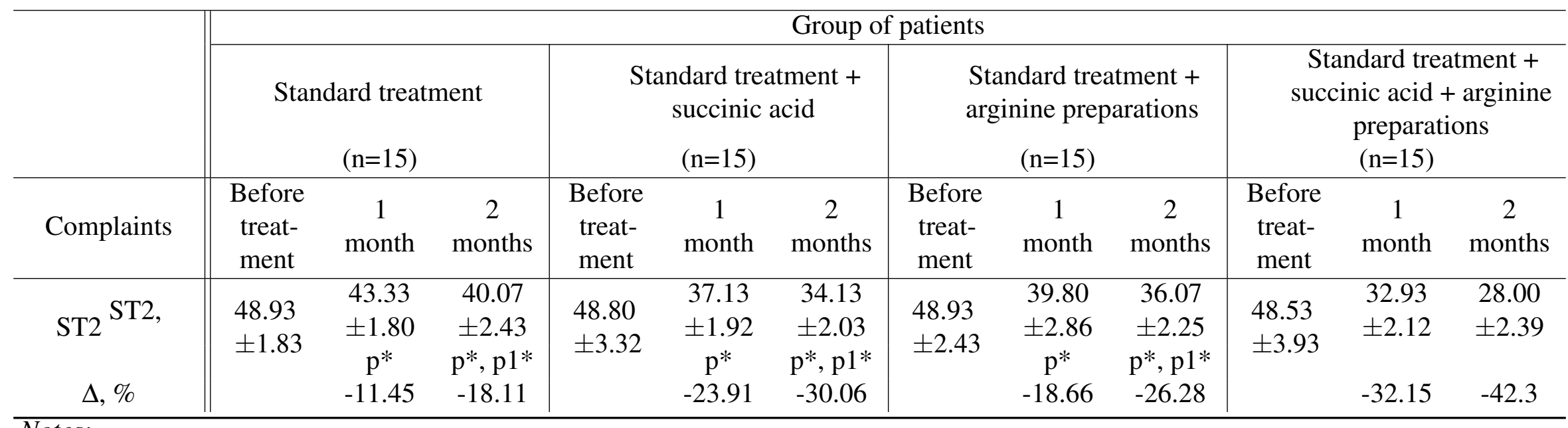

Notes:

1. the reliability of difference scores $\mathrm{p}$ - as compared to the indicators before treatment; $\mathrm{p} 1$ - as compared to the indicators 1 month after the beginning of treatment; $*-p<0.05, * *-p>0.05$.

2. $\Delta$ - the increase or reduction (-) in the indicator during the course of treatment as a percentage to the values before treatment. 


\section{Changes in the Levels of Modern Biomarkers in Patients with Decompensated Heart Failure After Myocardial Infarction Under the Influence of Treatment with Succinic Acid and Arginine \\ Preparations - 10/12}

cantly by $18.11 \%$ to $(40.07 \pm 2.43) \mathrm{ng} / \mathrm{ml}(\mathrm{p}<0.05)$ after the end of treatment. There was observed a reduction in serum level of ST2 in the patients, who received succinic acid on the background of standard therapy as well. In this group, the indicator was $(48.80 \pm 3.32) \mathrm{ng} / \mathrm{ml}$ before treatment, and $(37.13 \pm 1.92) \mathrm{ng} / \mathrm{ml}$ and $(34.13 \pm 2.03) \mathrm{ng} / \mathrm{ml}$ 1 and 2 months after the beginning of treatment, respectively $(\mathrm{p}<0.05)$. In the patients of Group III, serum level of ST2 was $(48.93 \pm 2.43) \mathrm{ng} / \mathrm{ml}$ before treatment; 1 and 2 months after the beginning of treatment, it was $(39.80 \pm 2.86) \mathrm{ng} / \mathrm{ml}$ and $(36.07 \pm 2.25) \mathrm{ng} / \mathrm{ml}$, respectively $(\mathrm{p}<0.05)$ that was $18.66 \%$ and $26.28 \%$ lower as compared to the initial data. In the patients of Group IV, serum concentration of ST2 before treatment was $(48.53 \pm 3.93) \mathrm{ng} / \mathrm{ml}$, significantly reducing by $32.15 \%$ and $42.30 \% 1$ and 2 months after the beginning of treatment to $(32.93 \pm 2.12) \mathrm{ng} / \mathrm{ml}$ and $(28.00 \pm 2.39) \mathrm{ng} / \mathrm{ml}$, respectively $(\mathrm{p}<0.05)$.

Thus, the use in patients after QQS and non-Q MI, complicated by decompensated HF, succinic acid and arginine preparations, can significantly reduce the level of immunological enzymes, which indicate the presence and development of cardiac decompensation. Thus, it was proved that the addition of these drugs to the base therapy was accompanied by the most pronounced decrease in the levels of ST2 and NT-proBNP both at rest and after exercise $(\mathrm{p}<0.05)$.

\section{Prospects of Further Researches}

Since the determination of serum concentration of NTproBNP and ST2 in the patients with decompensated HF secondary to MI is promising when analyzing treatment outcomes, further study of using multiple-marker quality assessment and individual treatment perception is required.

\section{Conclusions}

Natriuretic peptides are currently widely used in daily clinical practice not only in case of a large number of hospitalized patients with decompensated HF as confirmed by clinical trials. The issue of multiple biomarker strategy for HF therapy in the early and late post-infarction period is an extremely important and promising part of further research in this field.

The introduction of ST2 into routine practice, alongside with the use of NT-proBNP, will significantly reduce hospital costs by reducing the number of re-hospitalizations, canceling or replacing inactive drugs and improve quality of life in the patients with decompensated HF.

The use of succinic acid and arginine preparations, and especially their combination on the background of basic therapy, will significantly reduce serum concentration of NT-proBNP and ST2 in such patients, that, surely, confirms their positive therapeutic effect.

\section{References}

[1] Maisel AS, Richards AM, Pascual-Figal $D$ et al. Serial ST2 testing in hospitalized patients with acute heart failure. Am J Cardiol. 2015;115(7):32B37B. DOI: https://doi.org/10. 1016/j.amjcard.2015.01.038

[PMid:25682437]

[2] Nishimura M, Brann A, Chang K-W et al. The Confounding Effects of Non-cardiac Pathologies on the Interpretation of Cardiac Biomarkers. Curr Heart Fail Rep. 2018;15(4):239249. DOI: https://doi.org/10.1007/ s11897-018-0398-4 [PMid:29987498]

[3] Pascual-Figal DA, Januzzi JL. The Biology of ST2: The International ST2 Consensus Panel. Am J Cardiol. 2015;115(7):3B7B. DOI: https://doi.org/10. 1016/j.amjcard.2015.01.034 [PMid:25665766]

[4] Maisel AS, Di Somma S. Do we need another heart failure biomarker: focus on soluble suppression of tumorigenicity 2 (sST2). Eur Heart J. 2016;0:1-9. DOI: https://doi . org/10.1093/eurheartj/ehw 462

[PMid:28028009] 
[5] Maisel AS, Richards AM, Pascual-Figal $D$ et al. Serial ST2 Testing in Hospitalized Patients With Acute Heart Failure. Am J Cardiol. 2015;115:32B37B. DOI: https://doi.org/10. $1016 / j . a m j c a r d .2015 .01 .038$ [PMid:25682437]

[6] Ibrahim N, Januzzi JL. The potential role of natriuretic peptides and other biomarkers in heart failure diagnosis, prognosis and management. Expert Rev Cardiovasc Ther. 2015;13(9):10171030. DOI: https://doi.org/10. $1586 / 14779072.2015 .1071664$ [PMid:26198476]

[7] Ponikowski P, Voors A, Anker S et al. ESC Guidelines for the diagnosis and treatment of acute and chronic heart failure: The Task Force for the diagnosis and treatment of acute and chronic heart failure of the European Society of Cardiology (ESC). Developed with the special contribution of the Heart Failure Association (HFA) of the ESC. Eur Heart J. 2016;37:2129-3200. DOI: https://doi. org/10.1093/eurheartj/ehw128 [PMid:27206819]

[8] Roberts E, Ludman A, Dworzynski K et al. The diagnostic accuracy of the natriuretic peptides in heart failure: systematic review and diagnostic meta-analysis in the acute care setting. $\mathrm{Br}$ Med J. 2015;350:h910. DOI: https: / / doi .org/ $10.1136 /$ bm j . h 910 [PMid:25740799 PMCid:PMC4353288]

[9] Gaggin H, Januzzi J. Biomarkers and diagnostics in heart failure. Biochim Biophys Acta. 2013;1832:2442-2450. DOI: https://doi.org/10.1016/j. bbadis. 2012 . 12 . 014 [PMid:23313577]

[10] Lopes D, Menezes Falcão L. Mid-regional pro-adrenomedullin and ST2 in heart failure: contributions to diagnosis and prognosis. Rev Port Cardiol. 2017;36(6):465-
472. DOI: https://doi.org/10.1016/ j.repc.2016.11.009 [PMid:28606358]

[11] Dieplinger B, Mueller T. Soluble ST2 in heart failure. Clin Chim Acta. 2015;443:5770. DOI: https://doi.org/10.1016/ j.cca.2014.09.021 [PMid:25269091]

[12] Fan PC, Chang CH, Chen YC. Biomarkers for acute cardiorenal syndrome. Nephrology (Carlton). 2018;23:68-71. DOI: https: / / doi.org/10.1111/nep.13473

[PMid:30298648]

[13] Juan W, Guo-Juan T, Li-Na H et al. Novel biomarkers for cardiovascular risk prediction. J Geriatr Cardiol. 2017;14:135-150.

[14] Yancy CW, Jessup M, Bozkurt B et al, 2013 ACCF/AHA guideline for the management of heart failure: a report of the American College of Cardiology Foundation/American Heart Association Task Force on Practice Guidelines. J Am Coll Cardiol. 2013;62:e147-e239. DOI: https://doi.org/10.1016/j.jacc. 2013.05.019 [PMid:23747642]

[15] O'Gara PT, Kushner FG, Ascheim DD et al. 2013 ACCF/AHA guideline for the management of ST-elevation myocardial infarction: a report of the American College of Cardiology Foundation/American Heart Association Task Force on Practice Guidelines. J Am Coll Cardiol. 2013;61:e78-e140. DOI: https://doi.org/10.1161/CIR. 0b013e3182742 cf 6 [PMid:23247304]

[16] Von Lueder TG, Krum H. New medical therapies for heart failure. Nat Rev Cardiol. 2015;12:730-740. DOI: https://doi. org/10.1038/nrcardio.2015.137 [PMid:26416006]

[17] Gaggin HK, Szymonifka J, Bhardwaj A et al. Head-to-head comparison of serial soluble ST2, growth differentiation factor-15, and highly-sensitive troponin $\mathrm{T}$ measurements in patients with chronic heart failure. JACC Heart 
Fail. 2014;2:65-72. DOI: https://doi . org/10.1016/j.jchf.2013.10.005 [PMid:24622120]

[18] Lupu S, Agoston-Coldea L. Soluble ST2 in Ventricular Dysfunction. Adv Clin Chem. 2015;69:139-159. DOI: https://doi . org/10.1016/bs.acc.2014.12.005 [PMid:25934361]

[19] Dieplinger B, Januzzi Jr, Steinmair M et al. Analytical and clinical evaluation of a novel high-sensitivity assay for measurement of soluble ST2 in human plasma - the Presage ST2 assay, Clin Chim Acta. 2009;409:3340. DOI: https://doi.org/10.1016/ j.cca.2009.08.010 [PMid:19699192]

[20] Lu J, Snider JV, Grenache DJ. Establishment of reference intervals for soluble ST2 from a United States Population. Clin Chim Acta. 2010;411:1825-1826. DOI: https://doi . org/10.1016/j.cca.2010.07.014

[PMid:20654603]

[21] Richards AM. ST2 and prognosis in chronic heart failure. J Am Coll Cardiol. 2018;72(19):2321-2323. DOI: https://doi.org/10.1016/j.jacc. 2018.08.2164 [PMid:30384888]

[22] Savic-Radojevic A, Pljesa-Ercegovac M, Matic M et al. Novel Biomarkers of Heart Failure. Adv Clin Chem. 2017;79:93-152. DOI: https://doi.org/10.1016/bs . acc.2016.09.002 [PMid:28212715]

[23] Khan SQ, O'Brien RJ, Struck J et al. Prognostic value of midregional pro-adrenomedullin in patients with acute myocardial infarction: the LAMP (Leicester Acute Myocardial Infarction Peptide) study. J Am Coll Cardiol. 2007;49:1525-1532. DOI: https://doi. org/10.1016/j.jacc.2006.12.038

[PMid:17418290]

[24] Tschöpe C, van Linthout S, Kherad B. Heart failure with preserved ejection fraction and future pharmacological strategies: a glance in the crystal ball. Curr Cardiol Rep. 2016;19(8):70. DOI: https://doi.org/10.1007/ s11886-017-0874-6 [PMid:28656481]

[25] Ziaeian B, Fonarow GC. Epidemiology and aetiology of heart failure. Nat Rev Cardiol. 2016;13:368-378. DOI: https://doi. org/10.1038/nrcardio.2016.25 [PMid:26935038 PMCid:PMC4868779]

[26] Lundgren J, Sandqvist A, Hedeland $M$ et al. Alterations in plasma Larginine and methylarginines in heart failure and after heart transplantation. Scand Cardiovasc J. 2018;52(4):196204. DOI: https://doi.org/10. $1080 / 14017431.2018 .1459823$

[PMid:29648475]

[27] Lundgren J, Soderlund C, Radegran G. Impact of postoperative pulmonary hypertension on outcome after heart transplantation. Scand Cardiovasc J. 2017;51:172181. DOI: https://doi .org/10.1016/ j.jtcvs.2011.02.028 [PMid:21596173 PMCid:PMC3244079]

Received: 2019-08-19

Revised: $2019-10-28$

Accepted: 2019-10-29 